Again, in time of war adolescents were given machine guns and told to shoot a man dressed up as an enemy. This was exciting and infinitely rewarding. It had an end product. Today, with no such opportunities, adolescents provide themselves with long poles and attach large cards to them supporting or denigrating whatever happens to be the current or available good or bad cause. There is little excitement in this. One could never suggest creating a war to make today's adolescents happy. But one must draw the inevitable conclusion that there is little for our eager adolescents today to find but mischief of their own making, and we should not too eagerly curse them for the drab society which we have created and in which we expect them to live.

\section{Help from Understanding}

What, then, should we do to help ? Firstly, I believe that young people themselves are looking round for security and leadership. Finding no astronauts, no moon rockets, no Nelsons nor Churchills, and few sportsmen or explorers on whom they can expend their emotions they are creating their own standards, forming their own societies, and throwing up their own heroes. These may not fit in with our ideas of what a hero should be, but at least we must accept that they are trying to fill a gap we have opened. Next, we should accept the credit for the fact that there now exist the basic conditions on which we would wish a new society to be built-well fed, well clothed, and well housed. Then I think we must recognize that these are our young and it is primarily up to us-particularly those of us who are teachers and doctors-to understand and to help them.

It may be that some of them want to go it alone. It may be that they seem not to want to meet us or to understand our point of view. Unless we are very close to them we shall never know, for they will be the last to tell us. It is probable that we shall have to be prepared to go a long way out of our way to help against a seemingly impenetrable wall of ingratitude, obstinacy, and resentment. I am sure that we shall often be hurt-but we shall all suffer less if we remember that we once existed inside this adolescent and that in a few years we shall be plain for him to see in himself. For that is how life goes on, and thus patience is part of "caring for."

Today's adolescent still carries the satchel, now heavy with books. The weight of it hanging from the left shoulder creates a scoliosis or exaggerates an appalling posture. The adolescent has a shinier morning face than ever we knew, for the majority enjoy school and run willingly towards it. The adolescent is discerning and inquisitive and remarkably conservative when one considers his superficial liberal outlook towards most of the incidents in his daily round and common task. He is still shy and sensitive to criticism of himself. He may kick a boy when he's down if someone happens to be with him at the time. But if he is alone and confident that no one is looking he will stoop down and pull the victim to his feet.

The boy wishes to be a man and the girl a woman. Therc is nothing strange in this. We were the same, and so were Socrates and the unknown writer on the Babylonian jars. All they ask is that we do not mock at them on their journey and that if we are there to help them at least we will let them appear to be helping themselves, and so make diplomacy a part of caring for. It is all terribly difficult and complicated. Sometimes the end product is one of great sorrow but more often, I submit, of enormous pride.

I know that my thesis on adolescents may shock many people, particularly, I think, psychiatrists and teachers. I would say by way of excuse that $I$ have lived for two decades surrounded by hundreds of other people's children. I am infinitely grateful to them that they have kept me young, at least in heart. I owe it to them in return that I should attempt, even if in a philosophic and unscientific way, to explain them to their parents and to suggest that they have made and are making the most out of this present civilization of ours-in spite of us.

Kahlil Gibran in The Prophet said:

Your children are not your children.

They are the sons and daughters of Life's longing for itself.

They came through you but not from you.

And though they are with you yet they belong not to you.

You may give them your love but not your thoughts,

For they have their own thoughts.

You may have their bodies, but not their souls,

For their souls dwell in the house of tomorrow, which you cannot visit, not even in your dreams.

You may strive to be like them, but seek not to make them like you.

For life goes not backward nor tarries with yesterday.

In conclusion, can I leave you with two thoughts? G. K. Chesterton said; "The only man who understood me was my tailor, who measured me afresh each time we met." When dealing with adolescents may I suggest that you measure them afresh each time you meet them-whether they be pupils or patients, sons or daughters, and no matter how short the interval between the meetings. And then, perhaps, we can take some consolation from Oscar Wilde, who said; "Children begin by loving their parents; as they grow older they judge them; sometimes they forgive them."

\title{
Red Cell Sodium in Hyperthyroidism
}

\author{
A. W. G. GOOLDEN, DIANA BATEMAN, SUSAN TORR
}

British Medical fournal, 1971, 2, 552-554

\section{Summary}

A simple method of measuring red cell sodium has shown that about $90 \%$ of thyrotoxic patients have values above the upper limit of the normal range. Patients taking 0.3 $\mathrm{mg}$ of L-thyroxine daily were found to have a signifi-

Department of Radiotherapy and Medical Research Council Cyclotron Unit, Hammersmith Hospital, London W12 0HS

A. W. G. GOOLDEN, M.B., D.M.R.T., Consultant Radiotherapist

DIANA BATEMAN, Technician
SUSAN TORR, B.SC., Technician cantly higher mean value for red cell sodium than that of the normal controls. It is suggested that patients taking this amount of thyroxine may be hypermetabolic. The determination of red cell sodium may prove useful as a measure of the peripheral action of thyroid hormone.

\section{Introduction}

The human red cell maintains relative to the serum a high concentration of potassium and a low concentration of sodium. The diffusion of sodium into the cell and of potassium out of the cell is balanced by the active transport of these cations 
against their respective concentration gradients. Sodium and potassium flux are linked in a pump which exchanges sodium inside the cell for potassium outside the cell (Hoffman, 1966). The activity of this pump is impaired in hyperthyroidism in which condition there are abnormalities in the transport of both sodium (Smith and Samuel, 1970) and potassium (Awwad and Goolden, 1961). These abnormalities are reversed when the hyperthyroidism is corrected.

Smith and Samuel (1970) showed that the rate constant for active sodium efflux was diminished in hyperthyroidism. This allowed the intracellular sodium concentration to rise until a new state of equilibrium was reached. They found that the mean red cell sodium concentration in hyperthyroid patients was significantly higher than that in control subjects. The relationship between cell sodium content and the active transport of sodium from the cell was linear in both normal and hyperthyroid individuals. The red cell sodium concentration may accordingly be used as an index of the abnormality in sodium transport in hyperthyroidism. We have measured red cell sodium in normal people and in thyrotoxic patients. The differences are such that this measurement may be used as an index of thyroid status.

\section{Subjects and Method}

Red cell sodium and potassium have been measured in the following groups.

Normal Controls (60).-These consisted of 28 malc and 32 female volunteers. Most of them were between the ages of 20 and 40.

Thyrotoxic Patients (60).- These with the exception of one child aged 11 , were between the ages of 20 and 70 . None of the patients had severe associated diseases but a few were in congestive cardiac failure. Patients taking cardiac glycosides were excluded. The diagnosis of thyrotoxicosis was made on clinical grounds and confirmed by two or more of the following tests: 20-minute uptake of ${ }^{99} \mathrm{mTc}$ by the thyroid (De Garreta et al., 1968), serum proteinbound iodine, serum thyroxine, and T3-Sephadex uptake (Gimlette, 1967).

Hypothyroid Patients (10).-The diagnosis of hypothyroidism was made on clinical grounds and confirmed by serum proteinbound iodine, T3-Sephadex uptake, and serum cholesterol.

Patients on Thyroxine (25).- All these patients had been previously treated for thyroid carcinoma and were taking $0.3 \mathrm{mg}$ of L-thyroxine daily. None of them were known to have metastatic disease. Seventeen patients had been thyroidectomized by a combination of surgery and ${ }^{131} \mathrm{I}$ therapy. The remaining eight were not necessarily athyroidal, but they had been maintained on thyroxine for some months and it is unlikely that they were deriving any thyroid hormone from endogenous sources. The mean value and range for red cell sodium in this latter group did not differ from the corresponding values in the totally thyroidectomized patients. Patients taking $0.3 \mathrm{mg}$ of $\mathrm{L}$-thyroxine have therefore been considered as a single group.

Patients with Miscellaneous Diseases. (20).-These included patients with malignant lymphoma, Hodgkin's disease, and polycythaemia vera and patients having radiotherapy or chemotherapy for a variety of conditions.

\section{MEASUREMENT OF RED CELL SODIUM AND POTASSIUM}

About $3 \mathrm{ml}$ of heparinized blood (1,000 units $/ \mathrm{ml}$ ) was centrifuged at 5,000 r.p.m. for about one minute. The supernatant plasma and buffy layer were removed and the cells were then washed four times with $5 \mathrm{ml}$ of cold iso-osmotic $\mathrm{MgCl}_{2}$. $\left(\mathrm{MgCl}_{2}\right.$ of $290 \mathrm{mOsm}$ may be prepared by dissolving $22.77 \mathrm{~g}$ of $\mathrm{MgCl}_{2} \cdot 6 \mathrm{H}_{2} \mathrm{O}$ in 1 litre of distilled water.) After removal of the fourth wash further $\mathrm{MgCl}_{2}$ was added so as to produce a packed cell volume of about $20 \%$ and the cell suspension was then mixed. The haematocrit reading was done with Wintrobe tubes which were centrifuged at $1,500 \mathrm{~g}$ for 30 minutes. A correction for trapped $\mathrm{MgCl}_{2}$ was made, the calibration curve of Chaplin and Mollison (1952) being used. This calibration curve applies to trapped plasma but can be used for $\mathrm{MgCl}_{2}$ with negligible error.

The remainder of the sample was centrifuged for about three minutes. As much supernatant as possible was removed with a graduated 2-ml pipette. It was replaced with an equal volume of deionized water with the same pipette which was emptied out completely by blowing out. The haemolysed blood was stored in a refrigerator overnight. After making appropriate dilutions sodium and potassium concentrations were determined with a Gallenkamp flame photometer.

\section{Results}

The mean value for red cell sodium expressed as $\mathrm{mmol} / \mathrm{l}$. of red cells was $7 \cdot 3 \pm$ S.D. 0.5 in the normal controls. The mean value in women was $7.2 \mathrm{mmol} / 1$. and in men $7.4 \mathrm{mmol} / 1$. but these differences were not significant. The coefficient of variation of the method was $0.735^{\circ} \%$. Repeated measurements of cell sodium in the same subject over a period of a year showed very little variation and were as follows: $8 \cdot 0,8 \cdot 2,8 \cdot 0,7 \cdot 8,7 \cdot 8,7 \cdot 8$, $7 \cdot 9,7 \cdot 9,7 \cdot 7$, and $7 \cdot 9 \mathrm{mmol} / 1$. In 10 subjects measurements were carried out on two separate occasions. The mean difference between values was less than $2 \%$.

Sodium and Potassium Contont of Red Cclls. Results expressed as mmol per litre of Red Cells

\begin{tabular}{|c|c|c|c|c|c|c|}
\hline & \multicolumn{3}{|c|}{ Sodium } & \multicolumn{3}{|c|}{ Potassium } \\
\hline & Mcan & S.D. & Rangc & Mcan & S.D. & Range \\
\hline $\begin{array}{l}\text { Normal controls }(60) \\
\text { Thyrotoxic paticnts }(60) \ldots \\
\text { Paticnts taking } 0.3 \mathrm{mg} \text { L- }\end{array}$ & $\begin{array}{r}7 \cdot 3 \\
10 \cdot 8\end{array}$ & $\begin{array}{l}0 \cdot 5 \\
2 \cdot 2\end{array}$ & $\begin{array}{l}6 \cdot 1-8 \cdot 4 \\
6 \cdot 8-18 \cdot 7\end{array}$ & $\begin{array}{l}97 \cdot 4 \\
97 \cdot 6\end{array}$ & $\begin{array}{l}5 \cdot 3 \\
5 \cdot 5\end{array}$ & $\begin{array}{l}86-105 \cdot 5 \\
82 \cdot 8-108 \cdot 9\end{array}$ \\
\hline thyroxine $(25)$ & $8 \cdot 9$ & 1.3 & $6 \cdot 9-12 \cdot 5$ & $97 \cdot 4$ & $5 \cdot 1$ & $83-104 \cdot 0$ \\
\hline
\end{tabular}

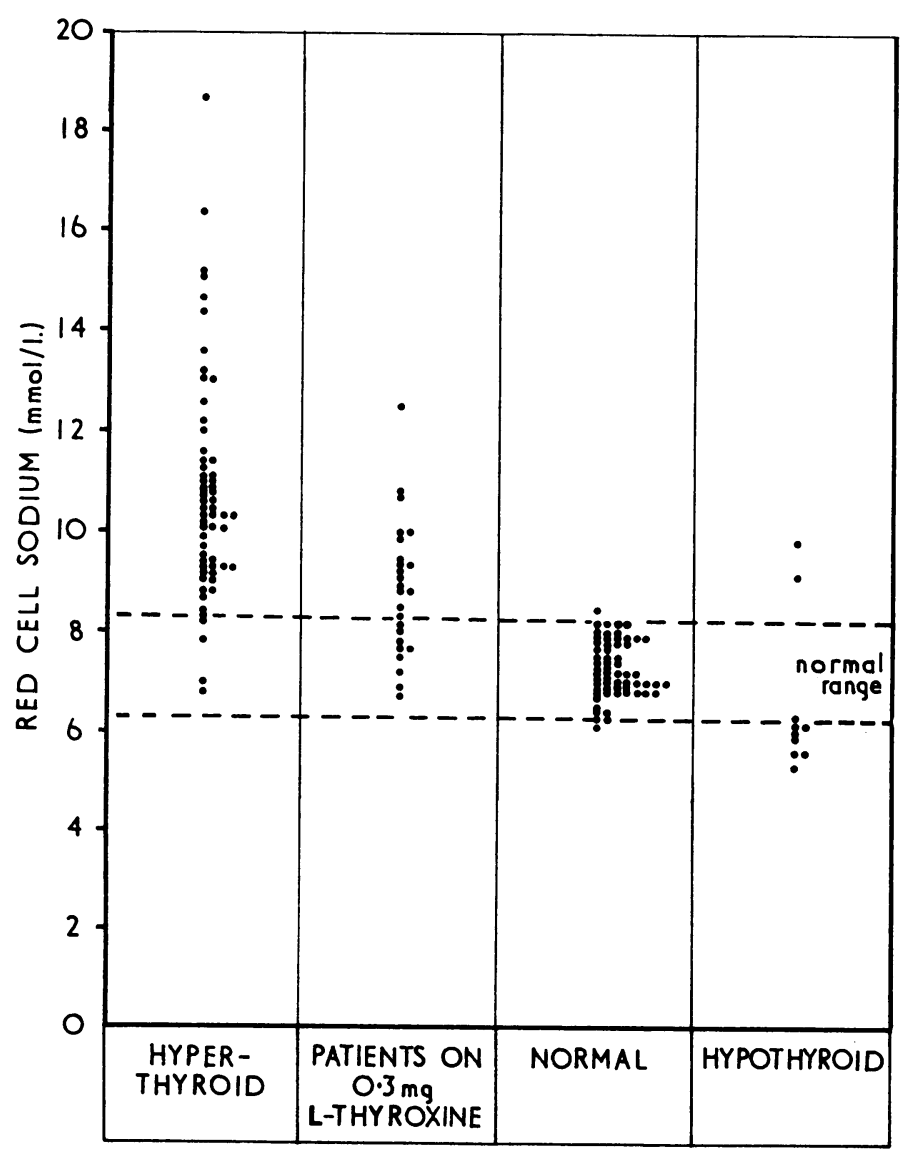

Values for red cell sodium in normal controls, hyperthyroid and hypothyroid patients, and patients taking a maintenance dose of $0.3 \mathrm{mg}$ of L-thyroxine daily. Results expressed as mmol per litre of red cells. 
Values for red cell sodium and potassium in the normal controls, thyrotoxic patients, and patients on thyroxine are shown in the Table. The mean value for cell sodium in thyrotoxic patients $(10 \cdot 8 \pm$ S.D. $2 \cdot 2 \mathrm{mmol} / 1$.) was much higher than that of the normal controls, this difference being highly significant $(P<0.001)$. About $90 \%$ of the thyrotoxic patients had red cell sodium values above the upper limit of the normal range (see Chart). Neither the protein-bound iodine nor the free thyroxine factor (Osorio et al., 1962) showed any correlation with red cell sodium. The mean value for red cell sodium in the patients taking thyroxine was $8.9 \pm$ S.D. 1.3 $\mathrm{mmol} / 1$. The difference between this group and the normal controls was also highly significant $(P<0.001)$. There was very close agreement in the mean value for red cell potassium between all three groups. In one patient the maintenance dose of thyroxine was reduced from 0.3 to $0.2 \mathrm{mg}$ daily. After a month on the lower dose red cell sodium had fallen from $9 \cdot 2$ to $7 \cdot 3 \mathrm{mmol} / 1$.

Red cell sodium was determined in three patients who were undergoing suppression tests. After taking L-triiodothyronine (T3) $120 \mu \mathrm{g}$ daily for a week cell sodium increased from 6.5 to $7.7 \mathrm{mmol} / 1$., from 8.0 to $8.4 \mathrm{mmol} / 1$, and from 8.6 to 9.9 $\mathrm{mmol} / 1$. respectively. Seven of the 10 hypothyroid patients had red cell sodium values below the normal range (see Chart). These values became normal when the hypothyroidism was corrected. Red cell sodium in the patients with miscellaneous diseases varied between 4.7 and $8.3 \mathrm{mmol} / 1$, being either within or more commonly below the normal range. None of these patients had raised values.

\section{Discussion}

Reported normal values for red cell sodium vary considerably (Valberg et al., 1965; Beilin et al., 1966a; Funder and Wieth, 1966). The main problem associated with this measurement has been that of finding a suitable method of correcting for trapped plasma. Most workers have utilized ${ }^{131} \mathrm{I}$-albumin for this purpose, but as Beilin et al. (1966b) pointed out this results in values which are erroneously high. The difficulties of correcting for trapped plasma are avoided if the cells are washed with a sodium-free solution. Our mean values for sodium and potassium in normal controls are in very good agreement with the results of Beilin et al. (1966a), who used ${ }^{14} \mathrm{C}$-sucrose to correct for trapped plasma, and with those of Smith and Samuel (1970), who washed the cells with $\mathrm{MgCl}_{2}$.

The method we have used for measuring red cell sodium is simple and gives reproducible results. The variation in any individual is remarkably small and the range for normal people lies within relatively narrow limits. A change of even $1 \mathrm{mmol} / 1$. of red cells can be readily detected and may be regarded as significant.

Boekelman (1958) reported that in a small group of hyperthyroid patients red cell sodium levels were higher than normal, and similar observations were made by Losse et al. (1966). Smith and Samuel (1970) confirmed these findings and demonstrated the defect in sodium transport which gave rise to the abnormality. In our experience red cell sodium is raised in most patients with thyrotoxicosis. Our patients were referred for thyroid function tests and were not selected in any way except for the exclusion of those who were known to be taking digoxin or digitalis. Two of the thyrotoxic patients who had normal values were in congestive cardiac failure, a condition in which depression of red cell sodium has been described (Czaczkes et al., 1967). The existence of raised red cell sodium values in such a high proportion of thyrotoxic patients suggests that it may be used for diagnostic purposes. Clearly it is important to know whether there are many other conditions which give rise to raised red cell sodium levels. It has been reported in patients with pseudohypertrophic muscular dystrophy (Dowben and Holley, 1959) and in some patients with severe renal failure (Welt et al., 1964). None of the small group of patients with miscellaneous diseases whom we have examined had raised sodium levels. Further information is needed, but probably raised levels are relatively uncommon in conditions other than thyrotoxicosis.

Seven of the 10 hypothyroid patients had low red cell sodium values though red cell potassium in this group was within the normal range. Normal values for cell sodium were found in those patients who were re-examined after correction of the hypothyroidism. A fall in the level of red cell sodium has been reported in various conditions, including cirrhosis of the liver and chronic renal failure (Czaczkes et al., 1967). On the basis of our limited experience it would seem to be a rather non-specific change and the measurement of red cell sodium is unlikely to have any practical application in the detection of hypothyroidism.

Our data suggest that red cell sodium provides a good indication of thyroid status, hyperthyroid individuals being largely separated from euthyroid individuals on the basis of this measurement. Reversal of the hyperthyroidism restores cell sodium to within the normal range. A few patients given T3 have shown a detectable rise in cell sodium after a week's treatment. There seems little doubt that the alteration in sodium transport which gives rise to raised cell sodium is provoked by an increase in the level of circulating thyroid hormone.

The patients taking thyroxine had a higher range and mean value for red cell sodium than did the normal controls. This poses the question of whether they are euthyroid. Though some feel better on a higher dose and a few prefer to take less most patients who need to take thyroid hormone feel well and show no signs of intolerance on $0.3 \mathrm{mg}$ of L-thyroxine daily. By general consensus they would be considered euthyroid. It could be argued that thyroxine might have a preferential effect on the sodium pump, but it would be surprising to find a qualitative difference of this nature between the two thyroid hormones. Furthermore, it has recently been shown that conversion of thyroxine to T3 takes place in vivo (Braverman et al., 1970). Patients taking thyroxine should therefore have both thyroid hormones available to the tissues. The alternative conclusion is that most patients taking what is usually regarded as an average replacement dose of thyroxine are in metabolic terms hyperthyroid.

Tests which depend on the peripheral effects of thyroid hormones are generally unsatisfactory and of much less diagnostic value than tests related to iodine metabolism or to the level of thyroid hormone in the blood. It would be advantageous to have available a test which reflected the peripheral action of thyroid hormone. Such a test would be useful for assessing thyroid status in situations where conventional tests were inappropriate or misleading. The measurement of red cell sodium may well prove useful for this purpose.

\section{References}

Awwad, H. K., and Goolden, A. W. G. (1961). Clinical Science, 20, 113. Beilin, L. J., Knight, G. J., Munro-Faure, A. D., and Anderson, J. (1966a). Fournal of Clinical Investigation, 45, 1817

Beilin, L. J., Knight, G. J., Munro-Faire, A. D., and Anderson, J. (1966b). fournal of General Physiology, 50,75.

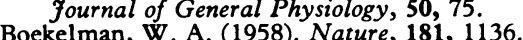

Braverman, L. E., Ingbar, S. H., and Sterling, K. (1970). Fournal of Clinical Investigation, 49, 855 .

Chaplin, H., and Mollison, P. L. (1952). Blood, 7, 1227.

Czaczkes, J. W., Aviram, A., Keynan, A., and Ullman, T. D. (1967). Israel fournal of Medical Science, 1, 137.

De Garreta, A. C., Glass, H. I., and Goolden, A. W. G. (1968). British fournal of Radiology, 41, 896 .

Dowben, R. M., and Holley, K. R. (1959). Fournal of Laboratory and Clinical Medicine, 54, 867.

Funder, J., and Wieth, J. O. (1966). Scandinavian fournal of Clinical and Laboratory Investigation, 18, 167

Gimlette, T. M. D. (1967). Fournal of Clinical Pathology, 20, 170.

Hoffman, J. F. (1966). American Fournal of Medicine, 41, 666.

Losse, H., Wehmeyer, H., and Zumkley, H. (1966). In Electrolytes and Cardiovascular Diseases, ed. E. Bajusz, vol. 2, p. 174. Baltimore, Williams and Wilkins.

Osorio, C., Jackson, D. J., Gartside, J. M., and Goolden, A. W. G. (1962). Clinical Science, 23, 525

Smith, E. K. M., and Samuel, P. D. (1970). Clinical Science, 38, 49.

Valberg, L. S., Holt, J. M., Paulson, E., and Szivek, J. (1965). fournal of Clinical Investigation, 44, 379.

Welt, L. G., Sachs, J. R., and MacManus, T. J. (1964). Transactions of the Association of American Physicians, 77, 169. 